\title{
Recent advances in immobilized enzymes on nanocarriers
}

\author{
Shilin Cao a,b,c,d, Pei Xu a,c, Yongzheng Mad , Xiaoxiao Yao ${ }^{d}$, Yuan Yao ${ }^{d}$, Minhua Zong a,b,c, Xuehui Li ${ }^{a}$, \\ Wenyong Lou ${ }^{\mathrm{b}, \mathrm{c}, *}$ \\ a School of Chemistry and Chemical Engineering, South China University of Technology, Guangzhou 510640, Guangdong, China \\ b State Key Laboratory of Pulp and Paper Engineering, South China University of Technology, Guangzhou 510640, Guangdong, China \\ c Laboratory of Applied Biocatalysis, School of Food Science and Engineering, South China University of Technology, Guangzhou 510640, Guangdong, \\ China \\ d Department of Applied Biology and Chemical Technology, The Hong Kong Polytechnic University, Hong Kong, China
}

\section{A R T I C L E I N F O}

\section{Article history:}

Received 29 July 2016

Accepted 18 August 2016

Published 5 November 2016

\section{Keywords:}

Enzyme immobilization

Cellulose nanocrystal

Polydopamine

Biodegradable material

\begin{abstract}
A B S T R A C T
Recent progress in nanotechnology has provided high-performance nanomaterials for enzyme immobilization. Nanobiocatalysts combining enzymes and nanocarriers are drawing increasing attention because of their high catalytic performance, enhanced stabilities, improved enzyme-substrate affinities, and reusabilities. Many studies have been performed to investigate the efficient use of cellulose nanocrystals, polydopamine-based nanomaterials, and synthetic polymer nanogels for enzyme immobilization. Various nanobiocatalysts are highlighted in this review, with the emphasis on the design, preparation, properties, and potential applications of nanoscale enzyme carriers and nanobiocatalysts.
\end{abstract}

(C) 2016, Dalian Institute of Chemical Physics, Chinese Academy of Sciences. Published by Elsevier B.V. All rights reserved.

\section{Introduction}

Catalysts are the basis of the chemical industry, and enzymes are important, highly efficient natural catalysts [1]. In recent years, the use of enzymes in industrial biotechnology has exploded [2], e.g., in the fine [3] and bulk chemical [4], food [5], pharmaceutical, cosmetic, textile, pulp, and paper industries [6]. However, the drawbacks of free enzymes, including high cost, poor operational stability, and challenges in recovery and reuse, have limited industrial applications of enzymes [7].

Enzyme immobilization is an efficient way of solving such problems. An enzyme immobilization technique should generally meet the following requirements [8]. First, the enzyme carrier needs to have good biocompatibility [9], a high specific surface area $[10,11]$, a suitable enzyme loading, and reusability. Secondly, the enzyme immobilization process should be simple and mild. Thirdly, the immobilized biocatalyst should have acceptable catalytic efficiency, stability [12], and promising potential applications [13]. Further investigation of simple and efficient enzyme immobilization techniques is therefore needed. In the past few years, much research has been devoted to the immobilization of enzymes in/on biodegradable nanoscale enzyme carriers such as cellulose nanocrystals (CNCs), polydopamine (PDA) nanocarriers, and biocompatible synthetic polymer nanogels.

In this review, we will summarize the preparation processes

\footnotetext{
* Corresponding author. Tel/Fax: +86-20-22236669; E-mail: wylou@scut.edu.cn

This work was supported by the National Natural Science Foundation of China (21336002, 21222606, 21376096), the Key Program of Guangdong Natural Science Foundation (S2013020013049), the Fundamental Research Funds for the Chinese Universities (2015PT002, 2015ZP009), the Program of State Key Laboratory of Pulp and Paper Engineering (2015C04), and the South China University of Technology Doctoral Student Short-Term Overseas Visiting Study Funding Project.

DOI: 10.1016/S1872-2067(16)62528-7 | http://www.sciencedirect.com/science/journal/18722067 | Chin. J. Catal., Vol. 37, No. 11, November 2016
} 
for the above enzyme carriers and discuss the use of these carriers for efficient enzyme immobilization. Some typical examples of enzyme immobilization processes are presented, and the structures and catalytic performances of these immobilized enzymes are discussed to provide guidance on designing better nanobiocatalysts.

\section{CNC-based nanobiocatalysts}

Biomacromolecules are biological polymers consisting of natural repeating units such as nucleic acids, proteins, and carbohydrates; they are sustainable, renewable, carbon neutral, biocompatible, and biodegradable. Biomacromolecular nanocarriers have recently been attracting increasing attention for use as efficient enzyme carriers. Cellulose, which is made up of amorphous and crystalline cellulosic components, is one of the most abundant biopolymers on Earth. When treated with acid (usually sulfuric acid and hydrochloric acid), the amorphous cellulosic components of cellulose raw materials are preferentially hydrolyzed. The retained cellulosic components with highly crystalline structures are CNCs [14]. CNCs can be extracted from several types of cellulose, e.g., ramie, bacterial cellulose, cotton, microcrystalline cellulose, and waste cotton fabrics [15]. CNCs have many excellent properties, including high surface-to-volume ratios, high aspect ratios, high stiffness, and good hardness and strength.

Yang et al. [16] were the first to report the use of CNCs as enzyme supports for peroxidase immobilization. The CNCs were activated with cyanogen bromide before being coupled with peroxidase. The results showed that the reaction temperature played a key role in the bonding reaction between the CNCs and peroxidase. The CNC-peroxidase bonding product was an isourea derivative at a low reaction temperature, about $25{ }^{\circ} \mathrm{C}$; however, $\mathrm{N}$-substituted imido carbonate and $\mathrm{N}$-substituted carbonic acid ester CNCperoxidase products were formed at a higher temperature (50 ${ }^{\circ} \mathrm{C}$ ). The activity of the immobilized peroxidase (594 U/g) was higher than that of free peroxidase, and it showed higher catalytic efficiency in removing chlorinated phenolic compounds in aqueous solution.

Boluk et al. [17] established a method for the preparation of CNC-based nanoscale biosensors via immobilization of glucose oxidase (GOx) from Aspergillusniger (Fig. 1). The CNC specific surface area was increased and the chemical affinity adjusted by coating CNCs (length $100 \mathrm{~nm}$ and width $10 \mathrm{~nm}$ ) with cationic polyethylenimine (PEI) via electrostatic assembly to form a CNC/PEI nanocomposite. Negatively charged $\mathrm{Au}$ nanoparticles (NPs) were then deposited on the CNCs/PEI electrostatically. The CNCs/PEI/AuNPs were modified with a thiol and used as an enzyme carrier to covalently immobilize GOx. The results showed that the amount of GOx loaded on the support increased with decreasing thiol-linker length; for example, the GOx loading increased from 20.3 to $25.2 \mathrm{mg} / \mathrm{g}$ support when the length of the thiol-linker decreased from 11 carbons to 3 carbons.

Lysozyme can be covalently immobilized via amide linkage of its glutamate and aspartate residues to the surfaces of amino-modified materials (Fig. 2). CNCs can be esterified by amino acids such as glycine because of the abundant hydroxyls on the CNC surface. Edwards et al. [18] prepared aminoglycine-CNCs and created lysozyme-amino-glycine-CNC conjugates using a carbodiimide-activated coupling reaction. The prepared nanobiocatalyst had a high enzyme loading (604 $\mathrm{mg} / \mathrm{g} \mathrm{CNCs}$ ) and high antimicrobial activity $(1500 \mathrm{U} / \mathrm{mg}$ biocatalyst) against Micrococcus lysodeikticus.

Kim et al. [19] immobilized lipase on CNCs via physical adsorption. The enzyme loading via adsorption on CNCs was 1.8-2.2 times higher than that on cellulose straw; this can be explained by enhanced electrostatic interactions between CNC sulfonate groups and lipase, and the increase in the CNC specific surface area.

These studies clearly show the great potential and research value of CNCs as an efficient enzyme carrier. However, the prepared CNCs are highly stable in aqueous suspension and difficult to separate from the reaction media without using high-speed centrifugation, and this has limited their applications. In an industrial enzymatic process, separation of the biocatalyst from the reaction system and its reuse in the next reaction cycle must be easy and convenient.

The introduction of magnetic $\mathrm{Fe}_{3} \mathrm{O}_{4} \mathrm{NPs}$ (MNPs) into the CNC matrix is a feasible method for the production of well-dispersed and easily separated CNC-based nanomaterials. However, MNPs and CNCs both have negative surface charges, and this leads to unstable MNP deposition on CNCs. The negative charge also results in MNPs easily leaking from the CNC surfaces. Our group overcame this problem by preparing novel magnetic CNCs (MCNCs) with chitosan as an electrical crosslinker to combine the CNCs strongly with $\mathrm{Fe}_{3} \mathrm{O}_{4}$, using a simple

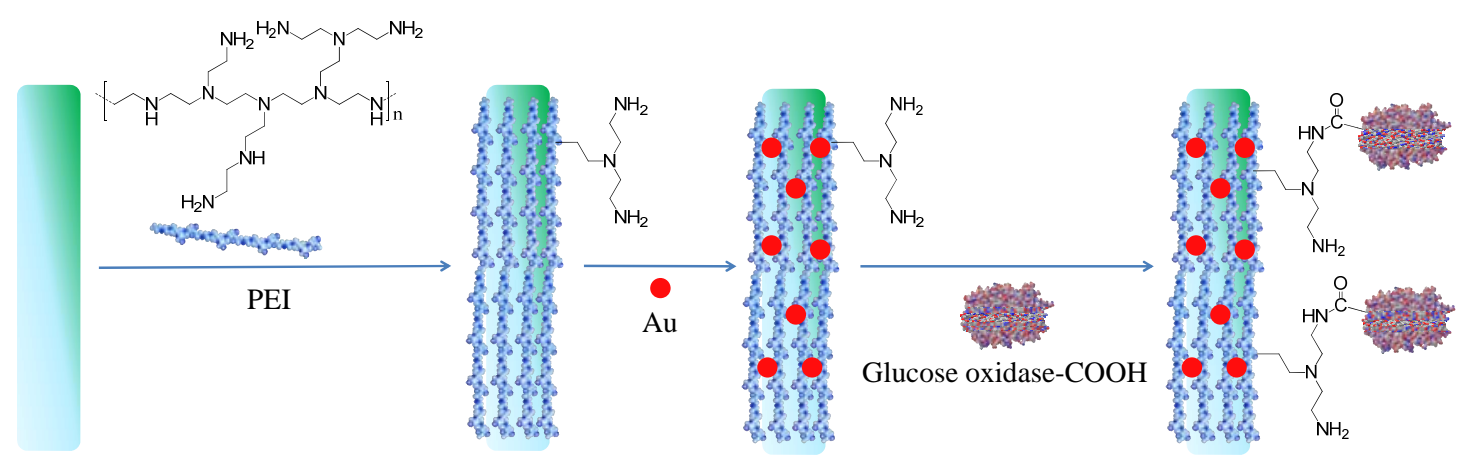

Fig. 1. Schematic diagram of experimental protocol for preparation of GOx-conjugated CNCs/PEI. 

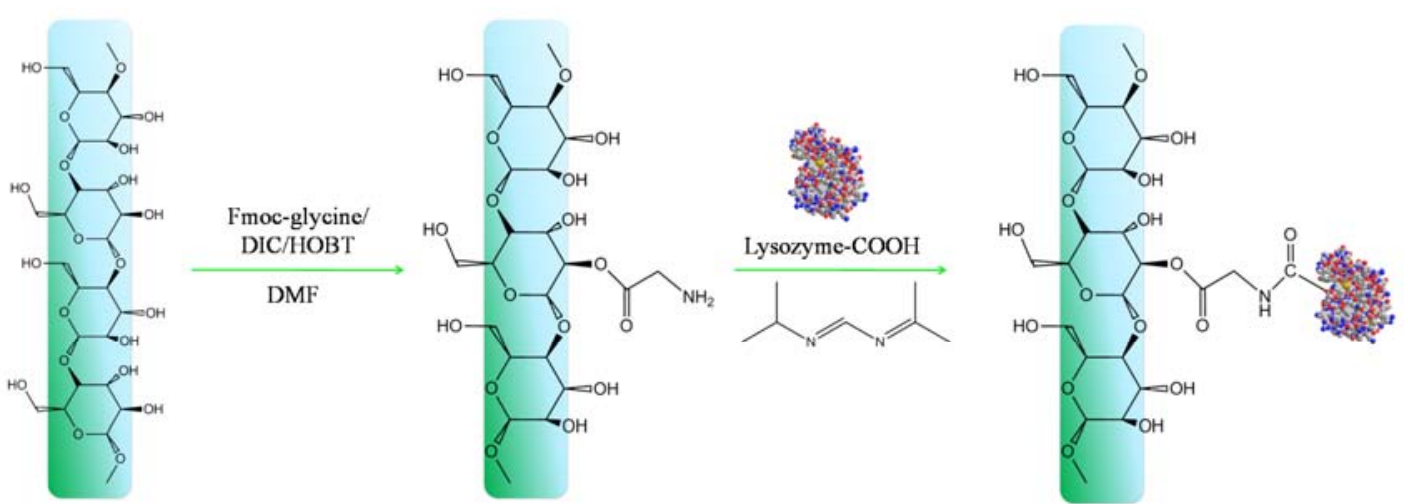

Fig. 2. Schematic diagram of experimental protocol for preparation of lysozyme-conjugated glycine-CNCs.

coprecipitation-electrostatic self-assembly technique (Fig. 3) [20]. Papain was successfully immobilized on the activated MCNCs. The immobilized papain showed relatively high catalytic efficiency in casein hydrolysis and was easily separated magnetically from the reaction system and recycled.

We developed a precipitation-crosslinking method to obtain biocatalysts with high enzyme loadings to open up new applications of MCNCs as enzyme carriers [8]. First, the enzyme was mixed with an aqueous suspension of the MCNC carrier. The enzyme was then deposited on the MCNC surfaces in the presence of a precipitant. Glutaraldehyde was added to crosslink the enzyme protein, which was tightly coated on the MCNC surfaces, to give an enzyme@MCNC biocatalyst (Fig. 4). Papain was immobilized on the MCNCs via the described precipitation-crosslinking process [8]. The results showed that the papain@MCNC biocatalyst had a high enzyme loading capacity (333 mg protein/g MCNCs) and high enzymatic activity recovery ( $>80 \%$ ). The catalytic efficiency and reaction activation energy of papain@MCNCs were higher and lower, respectively, than those of free papain.
The green and biocompatible choline chloride:urea deep eutectic solvent (DES) was first used by our group as the reaction medium for the efficient synthesis of an L-alanyl-L-glutamine (Ala-Gln) dipeptide precursor $[\mathrm{N}$ (benzyloxycarbonyl)-Ala-Gln] via an enzymatic reaction (Fig. 5). The yield obtained in DES was $71 \%$, whereas that in traditional aqueous solution was 33\%. The results of this study suggest that the reasons for the high efficiency of enzymatic dipeptide synthesis obtained using papain@MCNCs are as follows. First, the increased content of $\alpha$-helical structures in papain@MCNCs could help to retain the catalytic conformation of the enzyme molecules in DES media; secondly, the presence of DES in the reaction medium reduced the water content and suppressed side reactions. It should be noted that the structure and conformation of the free and immobilized papain in DES and DES-containing media both need to be further studied.

We immobilized Pseudomonas cepacia lipase (PCL) on MCNCs to obtain PCL@MCNCs with a high enzyme loading capacity (82.2 mg protein/g MCNCs), enzymatic activity recovery (95.9\%), enzyme-substrate affinity, catalytic

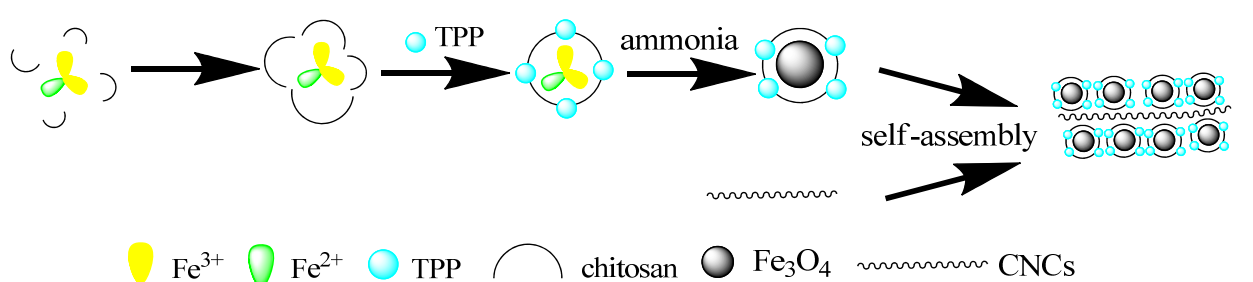

Fig. 3. Schematic diagram of experimental protocol for preparation of MCNCs.
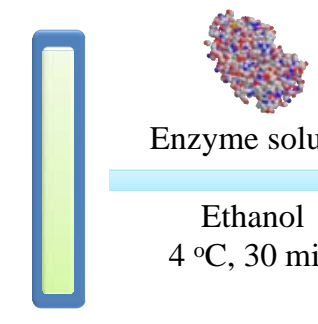

Enzyme solution

Ethanol

$4{ }^{\circ} \mathrm{C}, 30 \mathrm{~min}$

MCNC
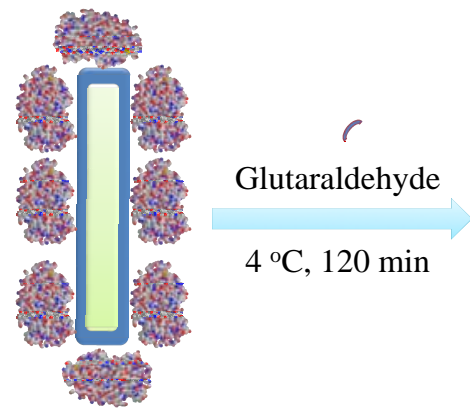

Enzyme@MCNC

Fig. 4. Schematic diagram of preparation of enzyme@MCNCs. 


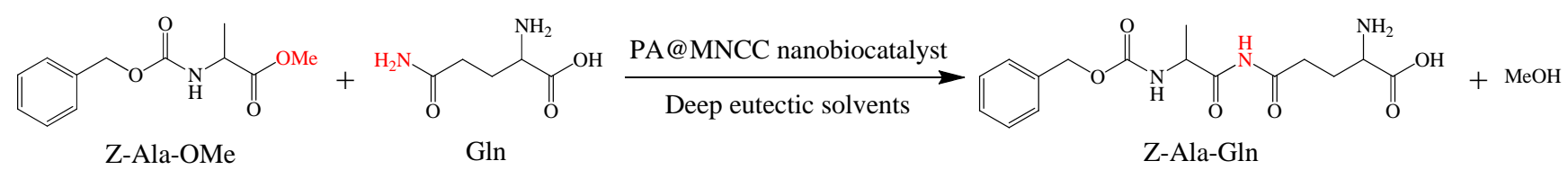

Fig. 5. Schematic diagram of papain@MCNC catalytic biosynthesis of Z-Ala-Gln.

efficiency, and stability [21]. We investigated and compared the secondary structures of free PCL and PCL@MCNCs. Precipitation-crosslinking increased the content of $\alpha$-helical structures by $3.03 \%$. According to a previous study, $\alpha$-helical structures reflect the structural rigidity and stability of an enzyme [22]. The enhancement of the PCL@MCNC stability by immobilization could therefore be a result of the increased $\alpha$-helix content. PCL@MCNCs therefore effectively catalyzed the asymmetric hydrolysis of ketoprofenethyl ester, with a high yield of $43.4 \%$ and product enantiomeric excess of $83.5 \%$.

Mahmoud et al. [23] embedded Au/magnetite NPs on CNCs to form a CNC/MNP/AuNP nanoconjugate (Fig. 6). The Au NPs and magnetite nanoparticles were stable and well dispersed on the CNC surfaces in the presence of thioctic acid. Papain was conjugated on the nanoconjugate using a two-step carbodiimide-coupling protocol. The optimum enzyme loading capacity was $186 \mathrm{mg}$ protein/g support.

\section{PDA-based nanobiocatalysts}

PDA is one of the most widely used biomimetic materials; it consists of a large number of dopamine (DA) units [24]. The biggest advantage of PDA (or DA) is that it can be easily deposited on most types of material surfaces, including inorganic (e.g., MNPs [25,26], halloysite [27], and mesoporous silica [28]) and organic (e.g., poly(allylamine hydrochloride) (PAH) [29], alginate [30], and chitin [31]) materials, by selfpolymerization of DA [32]. It is worth noting that the amine group of an enzyme can easily react with the catechol group of PDA via a Schiff base reaction [33]. Because of their good biocompatibility [34] and simple immobilization process [26], PDA-based carriers have recently gained increasing attention as novel enzyme supports [29].

Ren et al. [26] prepared magnetic iron oxide NPs coated with PDA (PDA-MNPs) and immobilized lipase on their surfaces using a simple method (Fig. 7). The results showed that the optimum immobilization conditions were PDA with DA deposited at a concentration of $2.5 \mathrm{mg} / \mathrm{mL}$ and a PD-MNPs to lipase mass ratio of 2:1. The immobilized lipase prepared under these conditions had a high enzyme loading (429 mg lipase/g PD-MNPs), high specific activity recovery $(73.9 \%$ of the free lipase activity), and better thermal and $\mathrm{pH}$ stabilities compared with its free counterpart. Importantly, the immobilized lipase showed good reusability and retained more than $70 \%$ of its initial activity after 21 cycles. These results show that PDAbased MNPs are economical, simple, and efficient carriers for enzyme immobilization.

Deng et al. [25] prepared mussel-inspired PDA-coated $\mathrm{Fe}_{3} \mathrm{O}_{4}$ (PD-MNPs) for efficient synthesis of dihydromyricetin3-acetate via enzymatic regioselective acylation (Fig. 8).

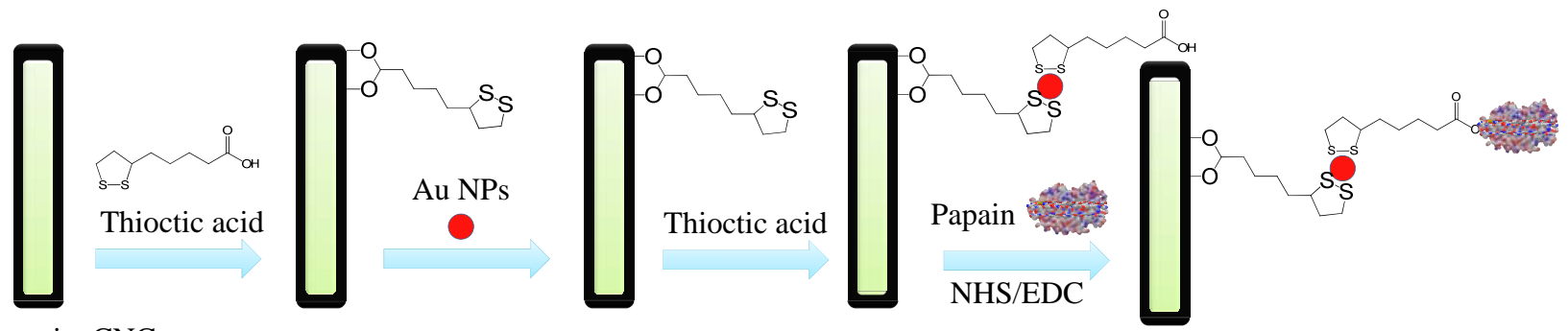

Magnetite CNC

Fig. 6. Schematic diagram of synthesis of papain@CNCs/MNPs/AuNPs.
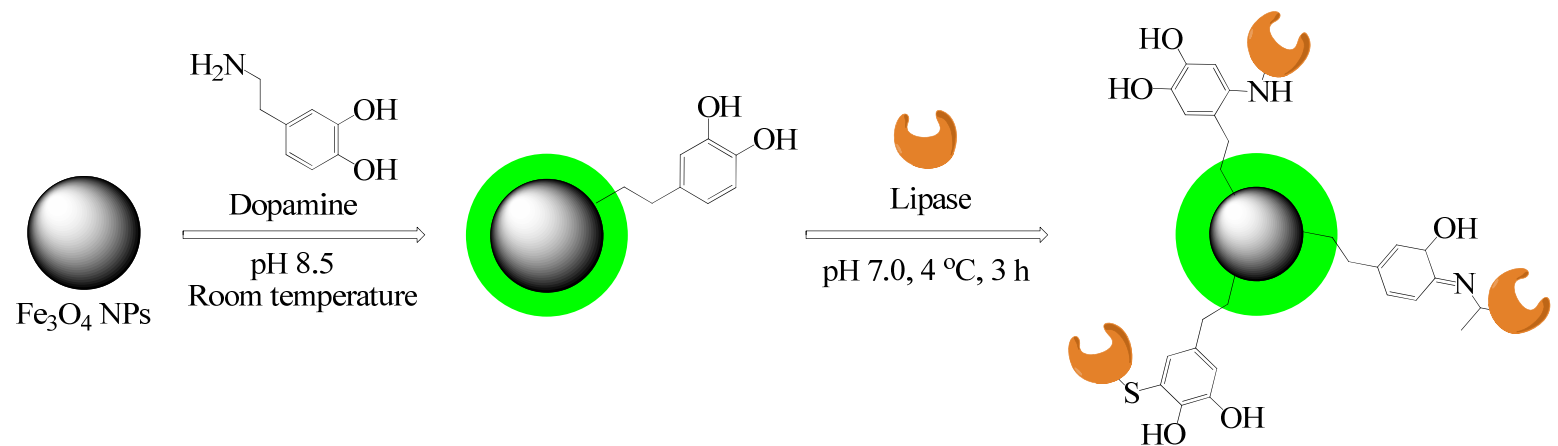

Fig. 7. Schematic diagram of lipase@PDA-MNP synthesis. 

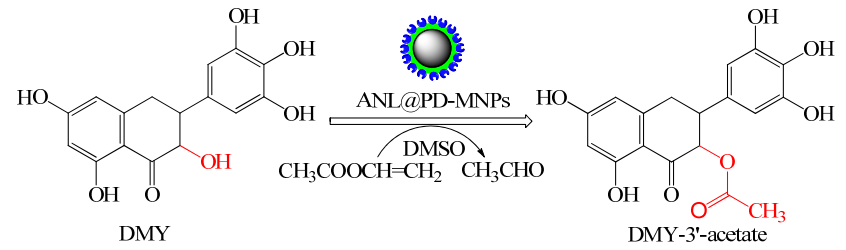

Fig. 8. Schematic diagram of ANL@PD-MNPs and ANL@PD-MNP-catalyzed esterification of DMY.

Aspergillusniger lipase (ANL) was successfully immobilized on PD-MNPs (ANL@PD-MNPs). The activity recovery of ANL@PD-MNPs was $83.6 \%$ and the enzyme loading ratio was 138 mg ANL/g PD-MNPs. The ANL@PD-MNPs showed better $\mathrm{pH}$, thermal, and storage stabilities, and higher enzymesubstrate affinity and catalytic efficiency than free ANL. Dihydromyricetin (DMY) is a natural flavonoid with efficient anti-inflammatory, analgesic, anti-thrombotic, and anti-tumor activities [35]. DMY esters have higher bioavailabilities and stabilities than free DMY molecules. Esterification catalyzed by lipase provides an environmentally friendly method for DMY ester synthesis [36]. Under the optimum conditions, the conversion in the reaction catalyzed by ANL@PD-MNPs in dimethyl sulfoxide (DMSO) was 79.1\%; however, it was only $67.1 \%$ when catalyzed by free ANL [25]. On the basis of these results, it was concluded that immobilization of ANL on PD-MNPs improved its catalytic performance in non-aqueous biocatalysis.

PDA, which is a surface modification agent, can be used to modify halloysite nanotubes (HNTs) to form PDA-HNTs. Laccase (EC 1.10.3.2) immobilized on PDA-HNTs showed high loading (168.79 $\mathrm{mg} / \mathrm{g})$, excellent thermal and storage stabilities, and reusability (retaining $70 \%$ of its activity after 10 cycles) [27]. The removal efficiency of 2,4-dichlorophen by immobilized laccase was $94 \%$. These results confirm that PDA-HNTs are effective carriers for enzyme immobilization.

Zheng et al. [28] developed a facile method for preventing protease release from mesoporous silica carriers. Their results indicated that the PDA layer effectively protected the enzyme from inactivation, with no significant mass transfer resistance detected. The immobilized enzyme also showed stably catalytic efficiency when subjected to proteolysis.

Shi et al. [29] prepared PAH-PDA microcapsules with three different wall structures using $\mathrm{CaCO}_{3}$ as a template. The activities and stabilities of these microcapsules were greatly affected by the PAH-PDA capsule structure: the more interconnected networks the capsule had, the higher the enzyme encapsulation efficiency. Its excellent activity and stability make this a promising candidate for biosensors and biocatalysts.
Core-shell magnetic PDA/alginate bionanocomposites [30] and PDA-coated magnetic-chitin particles [31] have been investigated as carriers for Candida rugosa lipase and amylase, respectively.

\section{Enzyme-synthetic polymer nanogels}

As well as being immobilized on biopolymer carriers, enzymes can also be surface modified using synthetic polymer nanogels such as polyacrylamide (PAM), monomethoxy poly(ethylene glycol) (MPEG), and $\mathrm{N}$-isopropylacrylamide (NIPAAm) to form enzyme-nanogel conjugates (ENCs). Immobilization can be achieved using "growing-from" and "grafting-to" processes.

The typical growing-from approach is a two-step process: (1) the lysine residue on the surface of the enzyme molecule is acylated to introduce a vinyl group; (2) the nanogel grows from the surface of the enzyme molecule by polymerization. Acryloyl chloride [37] and $N$-acryloxysuccinimide (NAS) [38] have been used as acylating agents in Step 1. NAS is preferable to acryloyl chloride because acetylation of the enzyme by NAS is much milder and does not lead to enzyme inactivation. Free-radical polymerization, atom-transfer-radical polymerization (ATRP), and reversible addition-fragmentation chain-transfer polymerization (RAFT) are the three approaches used in Step 2. Enzyme-PAM ENCs are generally prepared via free-radical polymerization, and temperature-responsive ENCs are obtained using ATRP and RAFT. In the grafting-to process, the enzyme is directly grafted with an end-functionalized polymer (e.g., Pluronic and hyperbranched aromatic polyamides) nanogel to form an ENC.

\subsection{Enzyme-polymer nanogels prepared via growing-from process}

\subsubsection{In situ free-radical polymerization}

Kim et al. [37] prepared an ENC consisting of single-enzyme NPs (SEN) via a three-step process (Fig. 9). First, chymotrypsin and trypsin were reacted with acryloyl chloride via their surface amino groups to form a vinyl-group-modified enzyme. After ultraviolet radiation, free-radical polymerization between the vinyl groups of the acrylated enzyme and methacryloxypropyl-trimethoxysilane (MAPS) was performed. After hydrolysis, the final products were obtained by condensation. The enzymatic activities of these SEN products were $38 \%-73 \%$. Transition electron microscopy images showed that the size of the chymotrypsin core was about 4-8 $\mathrm{nm}$, which is consistent with the size and shape of chymotrypsin $\left(4 \times 3 \times 8 \mathrm{~nm}^{3}\right)$. Kim et al. [37] found that the

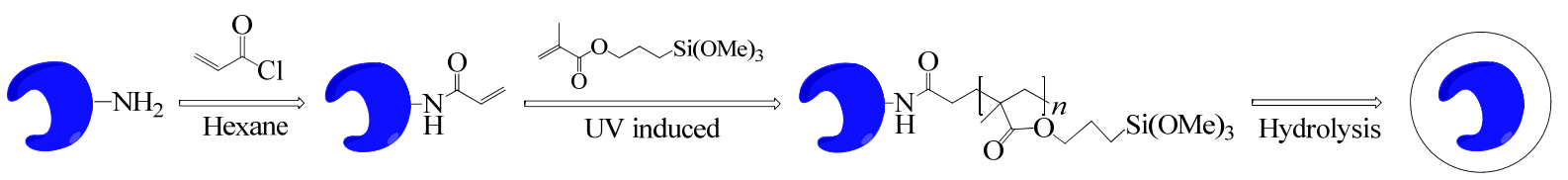

Chymotrypsin

Fig. 9. Schematic diagram of enzyme-polymer ENC synthesis. 


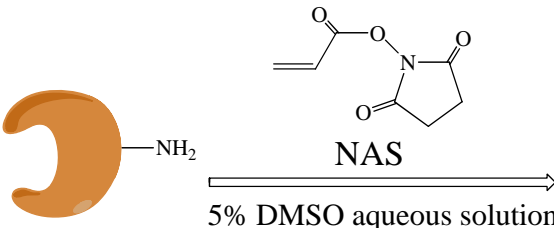

Horseradish peroxidase (HRP)

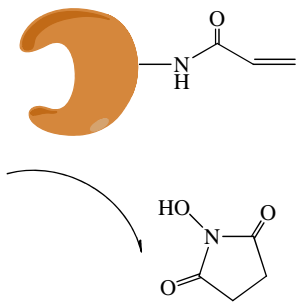

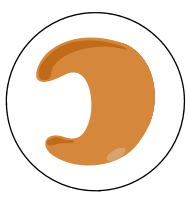

Bis-acrylamide

TMEDA

Single HRP-Poly(acrylamide) nanogel

Fig. 10. Schematic diagram of HRP-polymer ENC synthesis.

thickness of the outer layer network was related to the reaction conditions. The Michaelis constant $\left(K_{\mathrm{m}}\right)$ of the SEN was almost the same as that of the free enzyme, suggesting that the polymer network did not show significant mass transfer resistance.

Yan et al. [38] reported a two-step simple and efficient method for preparing a single horseradish peroxidase (HRP)-PAM ENC (Fig. 10). NAS was used instead of acryloyl chloride to achieve high enzymatic activity recovery. The HRP was first acetylized with NAS in 5\% DMSO aqueous solution. The acryloylated HRP was polymerized in situ with acrylamide in the presence of ammonium persulfate. The activity recovery of the HRP ENC was 91.8\%-92.0\%. Similar Michaelis-Menten parameters were observed for the free HRP and HRP-PAM ENC. This shows that the PAM polymer layer was thin enough to minimize transport resistance of the substrate to HRP and product discharge. The results show that the polar organic solvent tolerance was enhanced by the abundant hydrophilic groups in the PAM layer and multiple covalent attachments between HRP and the PAM shell.

The thermal inactivation and aggregation of bovine carbonic anhydrase (BCA) were investigated by Yan's group [39]. The carbonic anhydrases (CAs) are a family of zinc metalloenzymes that catalyze the reversible hydration of $\mathrm{CO}_{2}$ and water to produce bicarbonate and a proton [40]. These enzymes can also efficiently capture and convert $\mathrm{CO}_{2}$ both in vivo and in vitro. However, when used as a drug or catalyst, CAs are easily denatured and aggregated if the working temperature is higher than its unfolding temperature [41]. Yan et al. [39] found that the BCA nanogel was more thermally stable than, and had similar catalytic behavior to, BCA, as well as substrate accessibility. The melting temperature of the BCA ENC increased from 64 to $81{ }^{\circ} \mathrm{C}$ and the half-life of BCA increased from 5 to over 90 min compared with the free enzyme; this is attributed to polyacrylamide encapsulation of BCA. This encapsulation maintains the enzyme's secondary structure at high temperatures and inhibits BCA aggregation in water.

The molecular properties of lipase nanogels were studied by Ge et al. [42]. The acrylamide monomers were deposited on the enzyme in situ in aqueous solution via hydrogen bonds. These assemblies facilitated the subsequent polymerization to form the ENC. The formed hydrophilic PAM gel enhanced the enzyme stabilities in two ways: (1) the PAM gel led to intensified intramolecular hydrogen bonding in the lipase; (2) the hydrophilic environment in the PAM gel prevented the organic solvent from attracting water molecules [42].
Ge et al. [43] investigated the catalytic performance of a lipase ENC in anhydrous DMSO. DMSO and dimethyl formamide (DMF) are universal solvents and can be used to dissolve high-molecular-weight substrates. However, DMSO and DMF can strip the essential water molecules from the enzyme [44] and destroy its tertiary structure [45]. Few enzymatic reactions can therefore be performed in anhydrous DMSO and DMF. The lipase ENC maintained its catalytic activity in anhydrous DMSO and catalyzed transesterification between dextran and vinyl decanoate in anhydrous DMSO at $60^{\circ} \mathrm{C}$ for 10 d. The dextran ester degree of substitution was $23 \%$ and significant regioselectivity toward the C-2 hydroxyl group in the glucopyranosyl unit of dextran was observed. This lipase efficiently catalyzed dextran ester hydrolysis in aqueous solution [46].

Lin et al. [47] modified the enzyme-polymer conjugation method to fabricate a magnetic-support-loaded enzyme nanogel. Unlike in previous studies, the enzyme was first assembled with nanomagnetic particles via electrostatic assembly, and then the enzyme-nanomagnetic particle assemblies were polymerized in situ to form a PAM network. This strategy enabled enzyme encapsulation in the PAM nanogel without chemical modification, which greatly simplified the enzyme immobilization process and reduced deterioration of the enzyme conformation during aqueous polymerization. This magnetic enzyme-PAM nanogel can also be used for protein delivery and cellular metabolic manipulation.

Urate oxidase (UOX, EC 1.7.3.3) [48], superoxide dismutase (SOD) [49], enhanced green fluorescent protein [43], and caspase-3 [50] were successfully loaded on a PAM nanogel by in situ polymerization, and their stability was improved.

Table 1 shows some examples of enzyme-nanogels prepared via in situ free-radical polymerization.

\subsubsection{In situ ATRP and RAFT}

ATRP and RAFT are used as alternatives to simple freeradical polymerization for the synthesis of well-defined homogeneous protein-polymer ENCs because of their functional initiators.

ATRP is a mild reaction and can be conducted in aqueous solution at around room temperature, which is highly suitable for protein conjugation. Russell et al. [51] synthesized uniform chymotrypsin-poly(MPEG-methacrylate) ENCs by ATRP. The lysine residues of the chymotrypsin were first surface modified with 2-bromoisobutyryl bromide in aqueous phosphate buffer 
Table 1

Enzyme-nanogels prepared via in situ free-radical polymerization.

\begin{tabular}{|c|c|c|c|c|}
\hline Enzyme & $\begin{array}{c}\text { Acylating } \\
\text { reagent }\end{array}$ & Monomer & $\begin{array}{l}\text { Specific } \\
\text { activity } \\
(\%)\end{array}$ & Ref. \\
\hline Chymotrypsin & Acryloyl chloride & MAPS & $38-73$ & [37] \\
\hline Magnetic-trypsin & NAS & Acrylamide & $\sim 90$ & [47] \\
\hline HRP & NAS & Acrylamide & $91.8-92.0$ & [38] \\
\hline Magnetic-HRP & NAS & Acrylamide & $\sim 35$ & [47] \\
\hline BCA & NAS & Acrylamide & $\sim 70$ & [39] \\
\hline Lipase & NAS & Acrylamide & $\sim 85$ & {$[42,43,46]$} \\
\hline Magnetic-lipase & NAS & Acrylamide & $\sim 65$ & [47] \\
\hline Magnetic-CyC & NAS & Acrylamide & $\sim 80$ & [47] \\
\hline UOX & NAS & Acrylamide & $\sim 70$ & [48] \\
\hline SOD & NAS & Acrylamide & $\sim 90$ & [49] \\
\hline
\end{tabular}

to form chymotrypsin initiators. The chymotryps ininitiators were mixed with MPEG-methacrylate, and the reaction was performed at $40{ }^{\circ} \mathrm{C}$ for $16 \mathrm{~h}$. The resulting chymotrypsinpolymer ENCs were nearly monodisperse in terms of the number and molecular weight of the polymer chains attached per protein molecule.

Temperature-responsive enzyme-polymer ENCs were also prepared via ATRP [52]. The cysteine residues of a lysozyme were modified by pyridyl disulfide and maleimide endfunctionalized initiators. After mixing with NIPAAm monomers in water, lysozyme-PNIPAAm ENCs were obtained at ambient temperature by ATRP. Because of their high temperature responsiveness, the ENCs were easily separated from the reaction mixture by temperature-dependent collapse of the polymer chains [52].

RAFT can also be used to synthesize protein ENCs under mild conditions; for example, BSA was first modified using a water-soluble pyridyl disulfide-functionalized PEG-chain transfer agent. A BSA-PNIPAAm ENC was then formed via in situ RAFT. The temperature-dependent phase separation and aggregation behavior were well characterized [53].

\subsection{Enzyme-polymer nanogels prepared via grafting-to process}

Pluronics are a series of synthetic, non-toxic, neutral triblock copolymers consisting of a central hydrophobic poly(propylene oxide) (PPO) block and two hydrophilic poly(ethylene oxide) (PEO) side blocks; the molecular formula is $\mathrm{PEO}_{n}-\mathrm{PPO}_{m}-\mathrm{PEO}_{n}$ (Fig 11). A Pluronic triblock copolymer self-assembles into micelles in aqueous solution [54]. On exposure to a hydrophobic surface, the hydrophobic PPO block of the copolymer is absorbed at the hydrophobic interface and the two PEO segments extend into the hydrophilic medium [55].

A lysozyme-Pluronic F-127 ( PEO$_{99}-\mathrm{PPO}_{65}-\mathrm{PEO}_{99}$ ) ENC was prepared by Agnieszka et al. [54]. The Pluronic F-127 was
Ethylene oxide (EO) moieties:

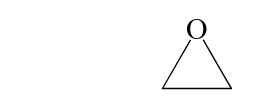

Propylene oxide (PO) moieties:

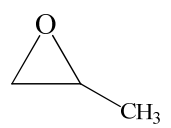

Hydrophobic block (PPO)
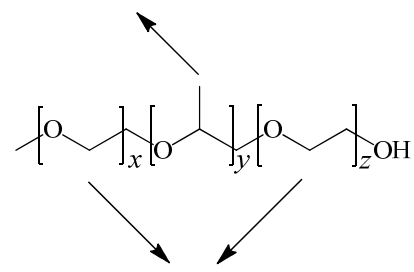

Hydrophilic block (PEO)

Fig. 11. Monomers and main chain of Pluronic F-127.

aldehyde-end-functionalized using Dess-Martin periodinane to form Pluronic-CHO and then the lysozyme was covalently conjugated with Pluronic-CHO via reductive amination between Pluronic-CHO and the basic amino acid residues in the protein (Fig. 12). Matrix-assisted laser desorption/ionization time-of-flight mass spectrometry showed that each Pluronic F-127 chain was linked with one or two lysozyme molecules. Pluronic-lysozyme ENCs were adsorbed on a hydrophobic Au-coated quartz surface in brush form and showed antibacterial activity toward Bacillus subtilis.

Pluronics are temperature responsive; temperature changes cause significant and discontinuous changes in their physical properties (Fig. 13) [56]. Based on this, Zhu et al. [57] improved the enzymatic process in organic media from heterogeneous to homogeneous catalysis. Bovine serum albumin (BSA), Candida rugosa lipase (CRL), Candida antarctic lipase B (CALB), and cytochrome $c$ (Cyt $c$ ) were conjugated with Pluronic to form BSA-Pluronic, CRL-Pluronic, CALB-Pluronic, and Cyt $c$-Pluronic ENCs. These enzyme-Pluronic ENCs were soluble in toluene at high temperature $\left(40{ }^{\circ} \mathrm{C}\right)$, enabling their use in homogenous reactions and recovery by temperature-induced precipitation at low temperature $\left(4^{\circ} \mathrm{C}\right)$. The activities of CALB-, CRL-, and Cyt c-Pluronic ENCs were 67-fold, 57-fold, and 670-fold higher, respectively, than those of the free enzymes. The significant increases in the enzyme activities depended on the hydrophobic PPO block of Pluronic, which enhanced the solubilities and stabilities of the enzyme-Pluronic ENCs and made the conjugated enzymes more accessible to the substrate in the reaction media [57]. The hydrophilic PEO blocks also helped to maintain favorable environments for enzymatic catalysis [43].

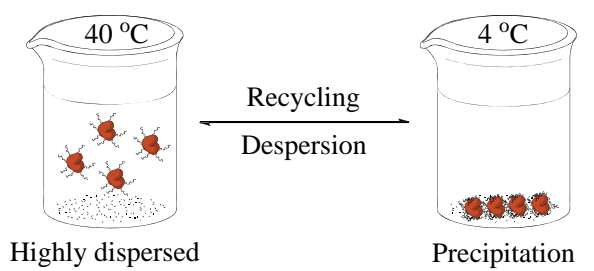

Fig. 13. Schematic diagram of temperature-induced precipitation of enzyme-Pluronic F-127 ENCs.

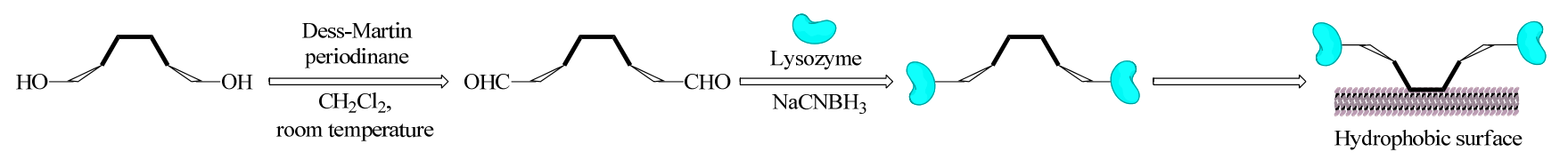

Fig. 12. Schematic diagram of lysozyme-Pluronic F-127 ENC synthesis. 


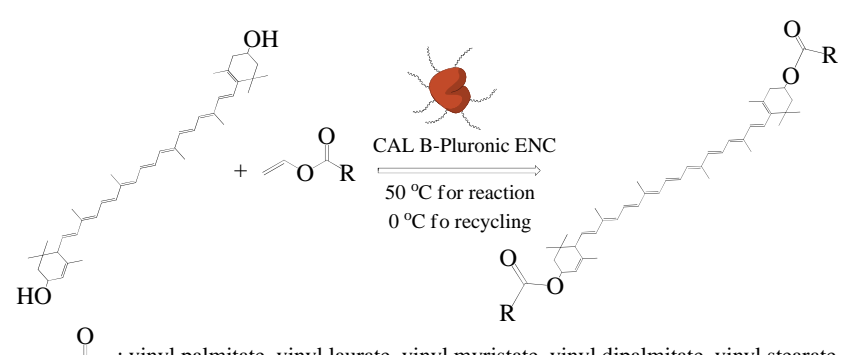

$\mathrm{O}_{\mathrm{R}}$ : vinyl palmitate, vinyl laurate, vinyl myristate, vinyl dipalmitate, vinyl stearate

Fig. 14. Lutein sterification using CALB-Pluronic F-127 ENC as bionanocatalyst.

CALB-Pluronic was successfully used in the esterification of lutein (Fig. 14) [58]. Lutein esters are widely used as an essential human dietary supplement. They can protect against blue-light damage to the retina and inhibit age-related macular degeneration. The bioavailabilities and stabilities of lutein esters are higher than those of free lutein molecules. The CALB-Pluronic-catalyzed conversion of lutein to lutein palmitate was $85.1 \%$ at $50{ }^{\circ} \mathrm{C}$ in methyl tert-butyl ether, whereas the free lipase only achieved $10 \%$ conversion. Lutein laurate, luteinmyristate, and lutein stearate were also successfully synthesized via similar processes, with conversions of $73.8 \%, 88.55 \%$, and $84.4 \%$, respectively [58].

To increase the conjugation efficiency of the enzyme and control the size of the enzyme-Pluronic ENCs, Wu et al. [59] used aldehyde-functionalized Pluronic as a surfactant for enzyme conjugation in water-in-trichloromethane reverse emulsions (Fig. 15). The immobilization yield of the enzyme was nearly $100 \%$, and the specific activity of the enzymePluronic ENC was as high as $220 \%$. The Pluronic created a biocompatible reverse emulsion for encapsulating enzymes without enzyme deactivation.

$\mathrm{Ge}$ et al. [60] used polycondensation to form a hyperbranched aromatic polyamide (HBPA) using $p$ phenylenediamine and trimesic acid as the monomers. A lipase was conjugated with HBPA using carbodiimide as a coupling reagent. The $K_{\mathrm{m}}$ of the lipase-HBPA ENC was similar to that of the free lipase, but increased by $20 \%$ at $V_{\max }$ for $p$ nitrophenylpalmitate hydrolysis. The abundant carboxyl groups on the HBPA surface provided a hydrophilic microenvironment to maintain the activity of the enzyme in organic solvents at high temperatures.

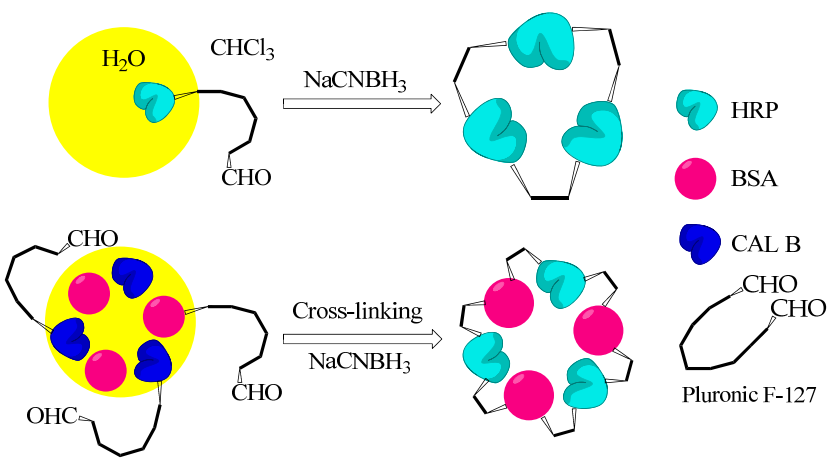

Fig. 15. Schematic diagram of preparation of enzyme-Pluronic ENCs in reverse emulsion.

\section{Summary and perspective}

Studies of enzyme immobilization using CNC- and PDA-based nanomaterials started in 2008 and 2011, respectively; single enzyme-polymer ENCs have been investigated since 2003. The research discussed in this review illustrates the great potential of novel materials for enzyme immobilization. Enzyme-CNC, enzyme-PDA, and enzymepolymer ENCs can significantly increase the catalytic activities, stabilities, and enantioselectivities of enzymes. Furthermore, enzyme-based biocatalytic processes are replacing traditional chemical conversion methods in laboratories and in industry because of their high efficiencies and eco-friendly properties.

However, there are still many key challenges for future research in these areas. First, the relationship between the CNC morphology (shape and aspect ratio) and catalytic performance of enzyme-CNC nanocomposites need to be further investigated. Secondly, the effects of the surface characteristics on the activities of enzyme-CNC nanocomposites are not yet understood. Thorough studies of these two topics will enable the rational design of enzyme-CNC nanocomposites to obtain highly efficient biocatalysts. Thirdly, PDAs have highly complicated structures, therefore it is necessary to explore the effects of enzyme-PDA interactions on the catalytic performance of enzymes. Fourthly, enzyme encapsulation in smart nanogels, e.g., pH-sensitive, photosensitive, and thermosensitive nanogels, to protect the enzymes in harsh solution environments or for recycling the enzymes under certain conditions is also a promising research direction. Finally, our understanding of the molecular properties of enzyme-CNCs, enzyme-PDAs, and ENCs needs to be improved by combining molecular simulations and practical experiments, to achieve higher performance by immobilized enzymes. We believe that intensive and extensive research on these topics will enable great progress in nanobiocatalyst development in the future.

\section{References}

[1] U. T. Bornscheuer, G. W. Huisman, R. J. Kazlauskas, S. Lutz, J. C. Moore, K. Robins, Nature, 2012, 485, 185-194.

[2] J. M. Choi, S. S. Han, H. S. Kim, Biotechnol. Adv., 2015, 33, 1443-1454.

[3] G. W. Zheng, J. H. Xu, Curr. Opin. Biotechnol., 2011, 22, 784-792.

[4] M. T. Reetz, J. Am. Chem. Soc., 2013, 135, 12480-12496.

[5] M. Misson, H. Zhang, B. Jin, J. R. Soc. Interface, 2015, 12(102), 1-20.

[6] H. E. Schoemaker, D. Mink, M. G. Wubbolts, Science, 2003, 299, 1694-1697.

[7] X. Wu, M. Hou, J. Ge, Catal. Sci. Technol., 2015, 5, 5077-5085.

[8] S. L. Cao, H. Xu, X. H. Li, W. Y. Lou, M. H. Zong, ACS Sustain. Chem. Eng., 2015, 3, 1589-1599.

[9] M. F. Wang, W. Qi, R. X. Su, Z. M. He, Chem. Eng. Sci., 2015, 135, 21-32.

[10] S. A. Ansari, Q. Husain, Biotechnol. Adv., 2012, 30, 512-523.

[11] T. Jesionowski, J. Zdarta, B. Krajewska, Adsorpt. J. Int. Adsorpt. Soc., 2014, 20, 801-821.

[12] S. L. Cao, D. M. Yue, X. Li, T. J. Smith, N. Li, M. H. Zong, H. Wu, Y. Z. Ma, W. Y. Lou, ACS Sustain. Chem. Eng., 2016, 4, 3586-3595.

[13] R. DiCosimo, J. McAuliffe, A. J. Poulose, G. Bohlmann, Chem. Soc. Rev., 2013, 42, 6437-6474. 


\section{Graphical Abstract}

Chin. J. Catal., 2016, 37: 1814-1823 doi: 10.1016/S1872-2067(16)62528-7

\section{Recent advances in immobilized enzymes on nanocarriers}

Shilin Cao, Pei Xu, Yongzheng Ma, Xiaoxiao Yao, Yuan Yao, Minhua Zong, Xuehui Li, Wenyong Lou* South China University of Technology; The Hong Kong Polytechnic University
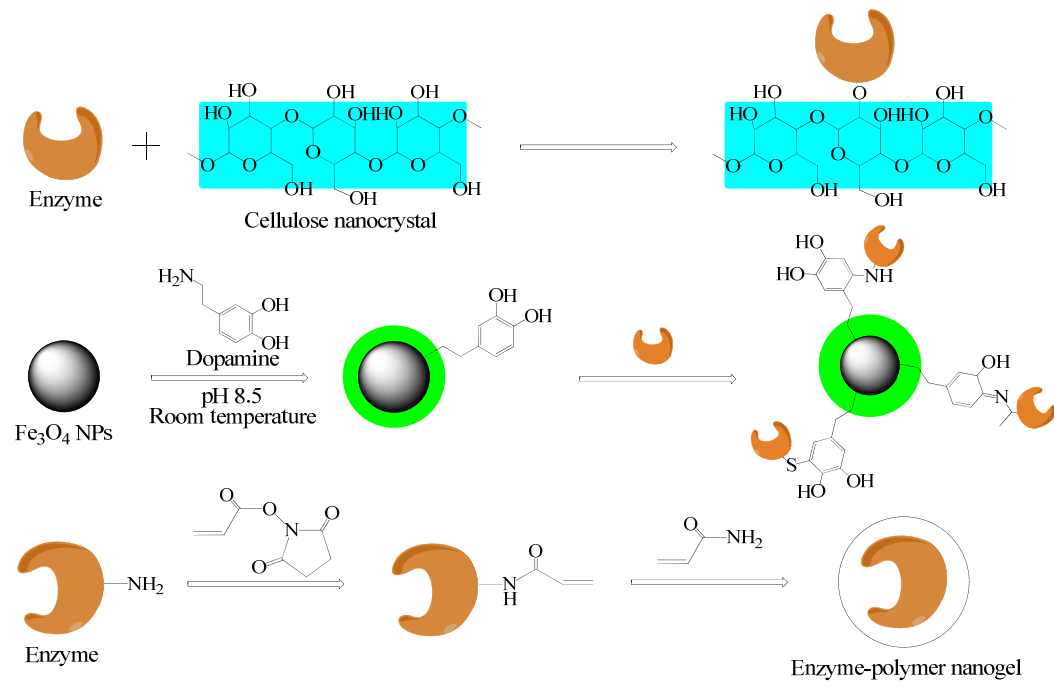

Various nanobiocatalysts, including cellulose nanocrystals, polydopamine-based nanomaterials, and synthetic polymer nanogels, are highlighted in this review, with the emphasis on the design, preparation, properties, and potential applications of nanoscale enzyme carriers and nanobiocatalysts.

[14] Y. Habibi, L. A. Lucia, O. J. Rojas, Chem. Rev., 2010, 110, 3479.

[15] R. Xiong, X. X. Zhang, D. Tian, Z. H. Zhou, C. H. Lu, Cellulose, 2012, 19, 1189-1198.

[16] R. M. Yang, H. Tan, F. L. Wei, F. Wang, Biotechnology, 2008, 7, 233-241.

[17] V. Incani, C. Danumah, Y. Boluk, Cellulose, 2013, 20, 191-200.

[18] J. V. Edwards, N. T. Prevost, B. Condon, A. French, Q. L. Wu, Cellulose, 2012, 19, 495-506.

[19] H. J. Kim, S. Park, S. H. Kim, J. H. Kim, H. Yu, H. J. Kim, Y. H. Yang, E. Kan, Y. H. Kim, S. H. Lee, J. Mol. Catal. B, 2015, 122, 170-178.

[20] S. L. Cao, X. H. Li, W. Y. Lou, M. H. Zong, J. Mater. Chem. B, 2014, 2, 5522-5530.

[21] S. L. Cao, Y. M. Huang, P. Xu, X. H. Li, H. Wu, N. Li, W. Y. Lou, M. H. Zong, Sci. Rep., 2016, 6, 20420.

[22] D. Eisenberg, Proc. Nat. Acad. Sci. USA, 2003, 100, 11207-11210.

[23] K. A. Mahmoud, E. Lam, S. Hrapovic, J. H. Luong, ACS Appl. Mater. Interface, 2013, 5, 4978-4985.

[24] J. J. Zhou, P. Wang, C. X. Wang, Y. T. Goh, Z. Fang, P. B. Messersmith, H. W. Duan, ACS Nano, 2015, 9, 6951-6960.

[25] X. Deng, S. L. Cao, N. Li, H. Wu, T. J. Smith, M. H. Zong, W. Y. Lou, Chin. J. Catal., 2016, 37, 584-595.

[26] Y. Ren, J. G. Rivera, L. He, H. Kulkarni, D. K. Lee, P. B. Messersmith, BMC Biotechnol., 2011, 11, 63.

[27] C. Chao, J. D. Liu, J. T. Wang, Y. W. Zhang, B. Zhang, Y. T. Zhang, X. Xiang, R. F. Chen, ACS Appl. Mater. Interface, 2013, 5, 1055910564.

[28] Y. Zheng, L. Zhang, J. F. Shi, Y. P. Liang, X. L. Wang, Z. Y. Jiang, Microporous Mesoporous Mater., 2012, 152, 122-127.

[29] J. F. Shi, C. Yang, S. H. Zhang, X. L. Wang, Z. Y. Jiang, W. Y. Zhang, X. K. Song, Q. H. Ai, C. Y. Tian, ACS Appl. Mater. Int., 2013, 5,
9991-9997.

[30] C. Hou, Z. G. Qi, H. Zhu, Colloids Surf. B, 2015, 128, 544-551.

[31] M. Sureshkumar, C. K. Lee, Carbohydr. Polym., 2011, 84, 775-780.

[32] H. Lee, S. M. Dellatore, W. M. Miller, P. B. Messersmith, Science, 2007, 318, 426-430

[33] Y. L. Liu, K. L. Ai, L. H. Lu, Chem. Rev., 2014, 114, 5057-5115.

[34] K. F. Ni, H. M. Lu, C. X. Wang, K. C. L. Black, D. Z. Wei, Y. H. Ren, P. B. Messersmith, Biotechnol. Bioeng., 2012, 109, 2970-2977.

[35] Y. Shen, A. K. Lindemeyer, C. Gonzalez, X. M. Shao, I. Spigelman, R. W. Olsen, J. Liang, J. Neurosci., 2012, 32, 390-401.

[36] W. Li, H. Wu, B. G. Liu, X. D. Hou, D. J. Wan, W. Y. Lou, J. Zhao, J. Biotechnol., 2015, 199, 31-37.

[37] J. Kim, J. W. Grate, Nano Lett., 2003, 3, 1219-1222.

[38] M. Yan, J. Ge, Z. Liu, P. K. Ouyang, J. Am. Chem. Soc., 2006, 128, 11008-11009.

[39] M. Yan, Z. X. Liu, D. N. Lu, Z. Liu, Biomacromolecules, 2007, 8, 560-565.

[40] D. N. Silverman, S. Lindskog, Acc. Chem. Res., 1988, 21, 30-36.

[41] N. S. Sarraf, A. A. Saboury, B. Ranjbar, A. A. Moosavi-Movahedi, Acta Biochim. Pol., 2004, 51, 665-672.

[42] J. Ge, D. N. Lu, J. Wang, M. Yan, Y. F. Lu, Z. Liu, J. Phys. Chem. B, 2008, 112, 14319-14324.

[43] J. Ge, D. N. Lu, J. Wang, Z. Liu, Biomacromolecules, 2009, 10, 1612-1618.

[44] L. Yang, J. S. Dordick, S. Garde, Biophys. J., 2004, 87, 812-821.

[45] T. Knubovets, J. J. Osterhout, A. M. Klibanov, Biotechnol. Bioeng., 1999, 63, 242-248.

[46] J. Ge, D. N. Lu, C. Yang, Z. Liu, Macromol. Rapid Commun., 2011, 32, 546-550.

[47] M. M. Lin, D. N. Lu, J. Y. Zhu, C. Yang, Y. F. Zhang, Z. Liu, Chem. 
Commun., 2012, 48, 3315-3317.

[48] Z. X. Liu, D. N. Lu, L. Yin, J. M. Li, Y. C. Cui, W. Chen, Z. Liu, J. Phys. Chem. B, 2011, 115, 8875-8882.

[49] M. Yan, J. J. Du, Z. Gu, M. Liang, Y. F. Hu, W. J. Zhang, S. Priceman, L. L. Wu, Z. H. Zhou, Z. Liu, T. Segura, T. Tatiana, Y. Tang, Y. F. Lu, Nat. Nanotechnol., 2010, 5, 48-53.

[50] Z. Gu, M. Yan, B. L. Hu, K. I. Joo, A. Biswas, Y. Huang, Y. Lu, P. Wang, Y. Tang, Nano Lett., 2009, 9, 4533-4538.

[51] B. S. Lele, H. Murata, K. Matyjaszewski, A. J. Russell, Biomacromolecules, 2005, 6, 3380-3387.

[52] K. L. Heredia, D. Bontempo, T. Ly, J. T. Byers, S. Halstenberg, H. D. Maynard, J. Am. Chem. Soc., 2005, 127, 16955-16960.

[53] C. Boyer, V. Bulmus, J. Q. Liu, T. P. Davis, M. H. Stenzel, C. Barner-Kowollik, J. Am. Chem. Soc., 2007, 129, 7145-7154.
[54] A. K. Muszanska, H. J. Busscher, A. Herrmann, H. C. van der Mei, W. Norde, Biomaterials, 2011, 32, 6333-6341.

[55] H. Otsuka, Y. Nagasaki, K. Kataoka, Curr. Opin. Colloid Interface Sci., 2001, 6, 3-10.

[56] J. P. Xu, X. Yang, L. P. Lv, Y. Wei, F. M. Xu, J. Ji, Langmuir, 2010, 26, 16841-16847.

[57] J. Y. Zhu, Y. F. Zhang, D. N. Lu, R. N. Zare, J. Ge, Z. Liu, Chem. Commun. 2013, 49, 6090-6092.

[58] M. Hou, R. Wang, X. Wu, Y. Zhang, J. Ge, Z. Liu, Catal. Lett., 2015 145, 1825-1829.

[59] X. L. Wu, J. Ge, J. Y. Zhu, Y. F. Zhang, Y. Yong, Z. Liu, Chem. Commun., 2015, 51, 9674-9677.

[60] J. Ge, M. Yan, D. N. Lu, M. L. Zhang, Z. Liu, Biochem. Eng. J., 2007, 36, 93-99.

\title{
纳米载体固定化酶的最新研究进展
}

\author{
曹诗林 ${ }^{a, b, c, d}$, 徐 培 ${ }^{\mathrm{a}, \mathrm{c}}$, 马永正 ${ }^{\mathrm{d}}$, 姚潇晓 ${ }^{\mathrm{d}}$, 姚 远 ${ }^{\mathrm{d}}$, 宗敏华 ${ }^{\mathrm{a}, \mathrm{b}, \mathrm{c}}$, 李雪辉 ${ }^{\mathrm{a}}$, 娄文勇 ${ }^{\mathrm{b}, \mathrm{c},{ }^{*}}$ \\ a华南理工大学化学与化工学院, 广东广州510640 \\ b华南理工大学制浆造纸工程国家重点实验室, 广东广州510640 \\ c华南理工大学食品科学与工程学院应用生物催化实验室, 广东广州510640 \\ d香港理工大学应用生物及化学科技系, 香港
}

\begin{abstract}
摘要: 催化剂是化学工业的重要基础, 其中酶是重要的高效天然催化剂. 近年来, 酶被越来越多地应用于工业领域, 如精细 化工、食品工业、制药工业、纺织业和制浆造纸. 然而, 由于游离酶存在价格昂贵及操作稳定性 (特别是回收与重复使用 性能) 低等缺点, 其在工业上的进一步应用受到一定限制. 对酶进行固定化是解决上述问题的有效途径. 一个理想的酶固 定化技术需要载体具有良好的生物相容性和高比表面积, 能够负载适量的酶并且具有很好的重复使用性能, 固定化酶的过 程简单温和, 所得到的固定化酶制剂具有良好的催化性能、稳定性以及工业应用价值. 尽管固定化酶技术经过了多年的发 展, 但仍需进一步研究.

近几年, 人们研究了基于纤维素纳米晶类、聚多巴胺类纳米载体以及生物相容性合成有机物纳米胶等新型载体对酶的 固定化, 取得了较好的成果. 本文综述了这些新型纳米载体的制备以及酶的固定化过程, 阐述了纳米载体固定化酶的结构 和催化性能, 并展望了发展前景.

纤维素是全球产量最高、来源最广的生物聚合物. 纤维素经过一定的酸 (常用硫酸和盐酸) 水解处理后,剩下的是具有 高结晶度的纤维素纳米晶. 它具有高比表面积、高机械强度和高长径比等优异性能. 因此, 研究者利用纤维素纳米晶作为 载体进行酶固定化, 获得了高负载量、高催化性能的固定化酶制剂.

基于仿生矿化法制备的聚多巴胺类材料近年来获得研究者越来越多的关注. 多巴胺具有良好的自聚合能力, 可以对无 机、有机等各种材料进行表面修饰. 同时, 聚多巴胺中含有的活性官能团可以与酶发生交联, 从而达到固定化酶的效果.

基于合成性聚合物纳米胶载体的固定化酶技术同样是一个新兴的、有意义的研究领域. 相关的固定化过程可分为两大 类: (1) 在酶分子表面通过原位聚合生成纳米胶 (growing-from 过程); (2) 将酶与预先合成的纳米胶进行交联 (grafting-to过 程). 其中, growing-from 过程是先将酶分子丙烯酰化, 再进行原位聚合. 而原位聚合又可分为自由基聚合、原子转移自由基 聚合 (ATRP) 和可逆加成-断裂链转移聚合 (RAFT). 其中, ATRP 和 RAFT 主要用于制备环境响应型的酶-聚合物纳米凝胶. 关键词: 酶固定化; 纤维素纳米晶; 聚多巴胺; 生物相容性材料
\end{abstract}

收稿日期: 2016-07-29. 接受日期: 2016-08-18. 出版日期: 2016-11-05.

*通讯联系人. 电话/传真: (020)22236669; 电子信箱: wylou@scut.edu.cn

基金来源：国家自然科学基金(21336002, 21222606, 21376096); 广东省自然科学基金(S2013020013049); 中央高校基本科研业务 费专项资金(2015PT002, 2015ZP009); 制浆造纸工程国家重点实验室(2015C04); 华南理工大学博士研究生短期境外访学项目. 本文的英文电子版由Elsevier出版社在ScienceDirect上出版(http://www.sciencedirect.com/science/journal/18722067). 